\title{
Short Communication: Correlated Selection Responses in Somatic Cell Count from Selection Against Clinical Mastitis
}

\author{
B. Heringstad, ${ }^{*}{ }^{1}$ E. Sehested, $\dagger$ and T. Steine $\dagger$ \\ *Department of Animal and Aquacultural Sciences, Norwegian University of Life Sciences, PO Box 5003, N-1432 Ås, Norway \\ †Geno Breeding and Al Association, PO Box 5003, N-1432 Ås, Norway
}

\begin{abstract}
Correlated selection responses in lactation mean somatic cell score (LSCS) were estimated for groups of cows selected for high protein yield and low mastitis frequency, respectively. Selection for increased milk production resulted in an unfavorable correlated response for LSCS, whereas direct selection against clinical mastitis resulted in a favorable correlated selection response. After 6 cow generations, the genetic difference between the high protein yield group and the low mastitis group was 0.3 units LSCS, equivalent to a difference in somatic cell count of approximately 15,000 , assuming deviations from a population mean LSCS of 4.1 .
\end{abstract}

Key words: clinical mastitis, correlated selection response, dairy cow, somatic cell count

Somatic cell count is a widely used indicator trait for mastitis, which in many countries is used as an indirect selection criterion for improving mastitis resistance (Interbull, 2008). This is based on the positive genetic correlation between clinical mastitis (CM) and SCC. Heringstad et al. (2000) found an average estimated genetic correlation between mastitis and SCC of 0.6 based on literature values. Recent estimates of the genetic correlation between mastitis and SCC range between 0.53 and 0.77 (Carlén et al., 2004; Ødegård et al., 2004; Koivula et al., 2005). Antagonistic genetic correlations have been found between SCC and milk production. Carlén et al. (2004) found genetic correlations ranging from 0.17 to 0.23 between lactation average SCS and milk production traits in first lactation. Correlated selection responses in SCC in opposite directions can therefore be expected when selecting for increased milk production or against mastitis. A Norwegian selection experiment, with 2 groups selected for high protein yield (HPY) and low CM prevalence

Received May 5, 2008.

Accepted June 23, 2008.

${ }^{1}$ Corresponding author: bjorg.heringstad@umb.no
(LCM), respectively, provided the necessary data to calculate such correlated responses in SCC. Large genetic differences in mastitis resistance have been reported from this selection experiment. After 5 cow generations, the genetic difference between the 2 selection groups approached 10 percentage units of CM (Heringstad et al., 2007). Our objective was to estimate correlated responses in lactation mean somatic cell score (LSCS) after selection for increased protein yield or against CM.

The selection experiment began in 1989 and included 8 herds, each with approximately the same number of cows in the 2 selection groups, HPY and LCM (Heringstad et al., 2003, 2007). The best proven sires for the given trait (protein yield or mastitis) were selected each year among the 120 to 130 progeny-tested Norwegian Red bulls and used as sires in the experiment. Cows in the HPY group were mated to 3 to 4 of the highest ranking proven sires for protein yield, and cows in the LCM group were mated to 2 to 4 of the best proven sires for mastitis resistance. Thus, the experiment was based on single-trait selection of sires preselected for the Norwegian Red breeding objective.

To take into account that sires were selected externally to the experiment, all available data from Norwegian Reds were analyzed with an animal model. The EBV for cows in the experiment were extracted from this analysis and used to calculate genetic trends in the selection groups. Data were from the Norwegian Dairy Herd Recording System and included SCC records of 2,596,758 first-lactation Norwegian Red cows. Cows with their first calving from January 1979 to July 2007 were included. Age at first calving had to be between 19 and 37 mo. Test-day SCS was calculated as $\log _{\mathrm{e}}(\mathrm{SCC} / 1,000)$. Mean lactation SCS was computed for cows with at least 2 test-day SCS records. The LSCS was precorrected for the effect of stage of lactation on test-day SCS by using the same procedure as used in the national genetic evaluation: LSCS = population mean SCS + mean deviations of test-day SCS from the standardized first-lactation SCS curve. The overall mean LSCS was 4.1. A total of 2,912 cows from the selection experiment had first-lactation LSCS records, 


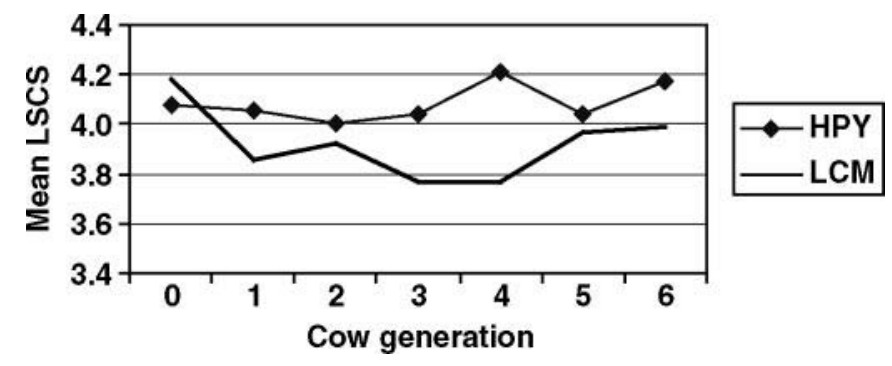

Figure 1. Lactation mean SCS (LSCS) in the first lactation per cow generation for groups of cows selected for high protein yield (HPY) and low clinical mastitis (LCM).

of which 1,519 were HPY cows and 1,393 were LCM cows.

For these analyses, all cows present in the herds when the selection experiment began that were mated with one of the defined sires and produced a daughter that made a first-lactation record were defined as belonging to cow generation 0 . Their daughters were defined as cow generation 1, and so on. Cows born in the same year could therefore belong to different cow generations. A pedigree file with 3,218,182 animals was created by tracing the pedigree of the cows with data as far back as possible.

A subset of the data, with 324,500 cows with LCSC records and a corresponding pedigree file with 903,504 animals, was used to estimate variance components. The resulting variance components were used as input parameters to calculate EBV based on the full data set with 2.6 million cows.

Variance components were estimated and breeding values for LSCS were predicted in an animal model by using the DMU-package (Madsen and Jensen, 2008). Following Ødegård et al. (2003), the model had the fixed effects of age at first calving (18 classes, from 19 to 37 mo), month of first calving (12 classes), and herd-year (547,603 classes), and the random effects of animal and residual. Genetic trends were assessed by plotting mean EBV per cow generation or per birth year.

The phenotypic level of LSCS has not changed much over time in either of the 2 selection groups (Figure 1). Mean LSCS was slightly larger in the HPY group throughout the experiment, and in cow generation 6 , mean LSCS was 4.2 in the HPY and 4.0 in LCM.

Estimated genetic and residual variances for LSCS were 0.11 and 0.69 , respectively, corresponding to a heritability of 0.14 , which is within the range of previous estimates of heritability of LSCS (Carlén et al., 2004; Ødegård et al., 2004).

Genetic trends for LSCS in the 2 selection groups are given in Figure 2. For the HPY group, mean EBV for LSCS increased from cow generation 0 to 4 and de-

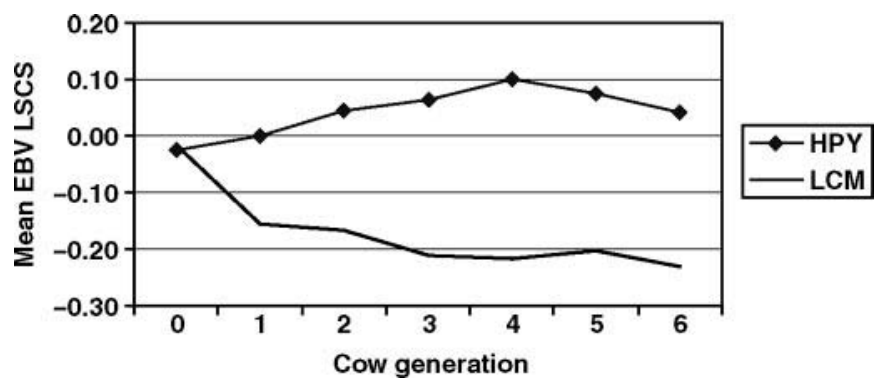

Figure 2. Mean EBV for lactation mean SCS (LSCS) per cow generation for groups of cows selected for high protein yield (HPY) and low clinical mastitis (LCM).

creased somewhat thereafter. Mean EBV for LSCS in the LCM group decreased from cow generation 0 to 3 , but after cow generation 3 , little or no genetic change was observed in this group. The genetic difference between groups was 0.3 units LSCS in cow generation 6 (Figure 2). The reduction of 0.21 units LSCS in the LCM group is equivalent to a reduction of 11,000 in SCC, whereas the increase in the HPY group of 0.07 units LSCS is equivalent to about 4,000 SCC, assuming deviations from the population mean LSCS (4.1). It should be noted that the population mean LSCS of 4.1, equivalent to 60,000 SCC, in Norwegian Red is low.

The genetic difference between selection groups (Figure 2) was somewhat larger and more pronounced than the phenotypic difference (Figure 1). Figure 3 shows that the genetic level of LSCS in the Norwegian Red population has not changed much over time, although there was a tendency for genetic improvement after 1997. The difference between mean EBV for cows with first calving in 1997 and 2007 was 0.05 units LSCS. Sires used in the selection experiment were selected among proven Norwegian Red sires, and genetic improvement in the Norwegian Red population may therefore explain the slightly decreasing trend for HPY after cow generation 4 (Figure 2). For the selection groups, the curves showing genetic trends by year (Figure 3) were less smooth than those showing trends by cow generation (Figure 2). This is because cows born in the same year may belong to different cow generations. However the overall picture is the same; EBV for LSCS increased over time in the HPY group and decreased in the LCM group.

Heringstad et al. (2007) estimated a genetic difference between LCM and HPY cows of 10 percentage units of CM. They found a steady improvement of mastitis resistance in the LCM group. Compared with this, the genetic change for LSCS seemed much slower, which was expected, because LSCS and CM are genetically correlated but are not the same trait. 


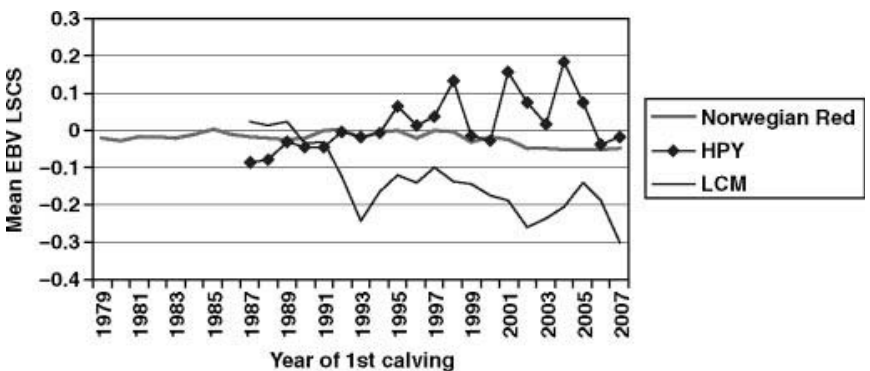

Figure 3. Genetic trend for lactation mean SCS (LSCS), given as mean EBV per year, for groups of cows selected for high protein yield (HPY) and low clinical mastitis (LCM), and for the Norwegian Red population.

Increased health costs as a correlated response to selection for increased milk production have been found in several studies (e.g., Short et al., 1990; Dunklee et al., 1994; Jones et al., 1994). Our study, however, is the first to report genetic change in LSCS as a correlated response to selection against CM.

\section{ACKNOWLEDGMENTS}

Geno Breeding and AI Association and the herds at Senter for husdyrforsøk, UMB, Åna kretsfengsel, and the agricultural schools Buskerud, Gjermundnes, Jønsberg, Kalnes, Mære, Valle, and Øksnevad are acknowledged for running the selection experiment. Access to the data was given by the Norwegian Dairy Herd Recording System and the Norwegian Cattle Health Service (Ås, Norway) in agreement number 004.2005. This work is part of project number 167893/I10 ("Avl for friskere kyr") financed by the Research Council of Norway (Oslo).

\section{REFERENCES}

Carlén, E., E. Strandberg, and A. Roth. 2004. Genetic parameters for clinical mastitis, somatic cell score, and production in the first three lactations of Swedish Holstein cows. J. Dairy Sci. 87:3062-3070.

Dunklee, J. S., A. E. Freeman, and D. H. Kelley. 1994. Comparison of Holsteins selected for high and average milk production. 2. Health and reproductive response to selection for milk. J. Dairy Sci. 77:3683-3690.

Heringstad, B., G. Klemetsdal, and J. Ruane. 2000. Selection for mastitis resistance in dairy cattle-A review with focus on the situation in the Nordic countries. Livest. Prod. Sci. 64:95-106.

Heringstad, B., G. Klemetsdal, and T. Steine. 2003. Selection responses for clinical mastitis and protein yield in 2 Norwegian dairy cattle selection experiments. J. Dairy Sci. 86:2990-2999.

Heringstad, B., G. Klemetsdal, and T. Steine. 2007. Selection responses for disease resistance in two selection experiments with Norwegian Red cows. J. Dairy Sci. 90:2419-2426.

Interbull. 2008. Description of national genetic evaluation systems for dairy cattle traits as applied in different Interbull member countries. http://www-interbull.slu.se/national_ges_info2/ framesida-ges.htm Accessed April 15, 2008.

Jones, W. P., L. B. Hansen, and H. Chester-Jones. 1994. Response of health care to selection for milk yield of dairy cattle. J. Dairy Sci. 77:3137-3152.

Koivula, M., E. A. Mäntysaari, E. Negussie, and T. Serenius. 2005. Genetic and phenotypic relationships among milk yield and somatic cell count before and after clinical mastitis. J. Dairy Sci. 88:827-833.

Madsen, P., and J. Jensen. 2008. A User's Guide to DMU: A Package for Analysing Multivariate Mixed Models. Version 6, release 4.7. Research Centre Foulum, Tjele, Denmark.

Ødegård, J., B. Heringstad, and G. Klemetsdal. 2004. Short communication: Bivariate genetic analysis of clinical mastitis and somatic cell count in Norwegian dairy cattle. J. Dairy Sci. 87:3515-3517.

Ødegård, J., G. Klemetsdal, and B. Heringstad. 2003. Variance components and genetic trend for somatic cell count in Norwegian cattle. Livest. Prod. Sci. 79:135-144.

Short, T. H., B. R. Bell, D. O. Richardson, H. H. Dowlen, E. D. Moore, and J. R. Owen. 1990. Correlated responses of health costs to selection for milk yield in Jerseys. J. Dairy Sci. 73:2547-2554. 